\title{
Geomorphic Environments of the Thakuran River of the Sunderbans, India
}

\author{
Gautam Kumar Das \\ Department of Chemical Engineering, Jadavpur University \\ Kolkata - 700 032, India \\ Email: gautamkrdas@yahoo.com
}

\begin{abstract}
The most recognizable geomorphic environments of the Thakuran Basin of Sunderbans are river systems of fluvial, estuarine and tidal nature, tidal creek system and sandy delta beaches. The roles played by these dynamic agencies have given rise to various erosional and accretional features throughout the drainage basin. Natural levee, point bar, mid channel bar, swash platform, wash over flat and ebb-tidal delta are some of the noteworthy geomorphic features present in the area. Severe bank erosion is observed in areas of high wave action near the mouth of Thakuran River. Point bars are generally fulcate to crescentic in shape with Epsilon Cross Stratification. Depending upon the distance from the sea, the mid channel bars show varying composition from mud to sand. Both banks of Thakuran River exhibit fringing mangrove vegetation. The distal end of the muddy swash platform supports luxuriant mangrove like Phoenix paludosa forests, which is the suitable abode for the famous Royal Bengal Tigers.
\end{abstract}

Keywords: River Bank, Natural Levee, Mid channel bar, Point bar, Marginal bar, Swash platform, Ebb-tidal delta

\section{Introduction}

The Thakuran River (latitude $21^{0} 35^{\prime}$ to $22^{0} 10^{\prime} \mathrm{N}$ and meridians $88^{0} 35^{\prime} \mathrm{E}$ ) is one of the many highly seasonal and tidal rivers flowing along the south coast of West Bengal, India (Fig. 1). It drains through the recent alluvial sediments of the Bengal Basin and flows more or less parallel to the Hugli River in the west and Matla in the east. The Thakuran has a funnel shaped estuary at its mouth having a width of approximately $8 \mathrm{~km}$. During the dry season the river regime is controlled by tidal water, whereas during rains the head water discharge has a strong influence over the river regime. Much of the estuarine plain is inundated by flood water during wet seasons but during dry seasons the estuarine plains are completely dried up and even register evidences of desiccation with salt encrustation. During dry time, the tidal flows are accumulated in the river channels. Discontinuous stretches of mangrove forests fringe the river.

The Thakuran River channel is characterized by the marginal point bars, mid channel bars and river mouth bar. Physical sedimentary structures are scattered on the point bar along convex and concave banks and upon the river bed of meandering estuarine stretch of the Thakuran River. The upper surface of the tidal shoals at the mid channel exhibits a gradual slope to the order of $12^{0}$ to $4^{0}$ downstream and is traversed by complex network of tidal creeks. 


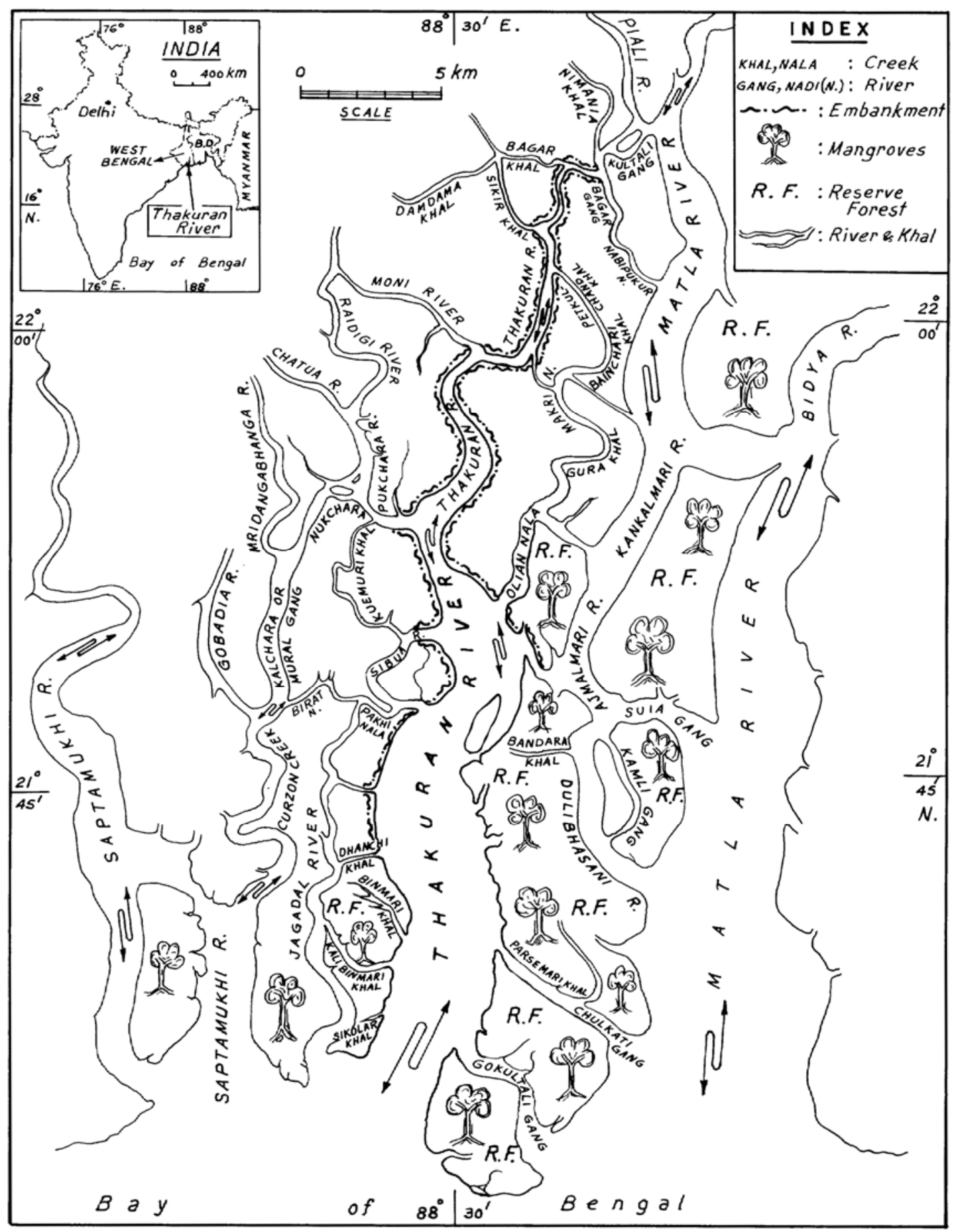

Fig. 1: River Thakuran with its connective drainage networks.

Rill marks of variable types and dimensions characterize the peripheral portions and indicate draining out of the trapped water during low water condition. Trench sections in the sand flats exhibit dominance of flaser and wavy bedding, whereas, lenticular bedding and starved ripple bedding dominate in the mudflats. Alternations of sand and mud deposits in 
variable proportions reflect deposition from bed load and suspended load characteristic of tide dominated high velocity ebb or flood currents and corresponding slack water condition.

The flood plains are almost horizontal and are composed of fresh water clays. These zones support vegetation of grasses, herbs and creepers, backwater swamps and fresh water pools. Field mapping has been done of the depositional sites, typically, the mid channel bar and marginal point bars.

\section{Flow Pattern}

Geomorphic environments of every meandering drainage system with its erosional and depositional sites are the resultant products of two distinct flow patterns: i) the downstream sinuous flow pattern and ii) the helicoidal flow pattern. The mid channel bar in a meandering system is either the result of slackening flow velocity due to channel topography or is a result of isolation of the point bars due to subsequent cut off by the later deflection of the water flow (Sarkar and Basumallick, 1968). In a tidal river the depositional behaviour of the channels are further very much sensitive to the seasonal variation of the tidal behaviour. The mid channel bars in Thakuran tidal river are mostly resultant from convergence of flood and ebb flows.

\section{Geomorphic Environments}

The estuarine environments and coastal configuration of the entire Sunderbans is the manifestation of riverine and/or coastal processes operated by several dynamic geomorphic agencies like estuaries (e.g. Hugli and Matla), tidal inlets (e.g. Thakuran, Saptamukhi) and numerous tidal creeks (e.g. Edward's, Pitt's) on the Ganga-Brahmaputra delta system (Coleman, 1969). Being positioned in the tropical meso-macrotidal setting with tidal amplitude between 2 and $5.5 \mathrm{~m}$, this coast is influenced by sediment drifts by tidal currents, waves and long shore currents of moderate intensity. Seasonal cyclonic storm surges take a significant role in the coastal modification. The fluctuating river regimes of the Ganges during the monsoon and pre/post monsoon seasons have significant contribution in the sediment budget of this coastal tract.

A complex network of geomorphic environments characterizes Thakuran tidal basin of the Sunderbans. Both sandy beaches and mudflats occur at the sea face depending on their locations on high and low energy zones respectively. Tidal rivers/inlets are generally muddy systems barring some sandy flats that occur in the mid channel bars and sandy swashy bars at the mouths of rivers/inlets. The creeks are absolutely muddy systems. Mangrove swamps occur on the intertidal mudflats of estuaries, creeks and inlets. Narrow marshes occur on the upper intertidal to the supratidal zones in a sporadic manner.

Three broad geomorphic environments can be recognized in Sunderbans. These are:

i. Fluvial, estuarine and tidal river systems with sand flats and mudflats

ii. Tidal creek systems with mudflats

iii. Sandy delta beaches

\section{Geomorphic Divisions}

Many geomorphic environments of deposition and erosion along and across the Thakuran River basin are noticeable. These are as follows:

i. River bank / Natural levees

ii. Point bars

iii. Mid channel bars 
iv. Swash platform

v. Wash over flat

vi. Ebb-tidal Delta

\section{Description of the Geomorphic Divisions}

\section{River Banks or Natural Levees}

Both banks of the river Thakuran are generally characterized by fringing mangroves. As a result, the nature of stratifications of the banks or that of the natural levee deposits is often heavily disturbed by roots and pneumatophores of mangroves and by the churning effect of burrowing organisms. In places of massive erosion, the banks have been fortified by construction of embankments. As a result, mangroves are truncated in the intertidal zone. Landward, the intertidal area behind the embankments is occupied by marsh vegetation (Bhattacharya, 1999). The topmost portions of the bank deposits register evidences of long exposures and contain desiccation cracks and salt-encrusted surfaces in patches. The following features characterize the supratidal bank deposits:

i. Marshy areas are characterized by marsh lamination with fine obscured laminae of silt and clay profusely disturbed by roots of marsh vegetation.

ii. Rapid thinning of sand laminae and dominance of mud in the upward direction bank deposits are evident in many bank sections (Fig. 2).

iii. Plant remains and plant roots constitute a substantial component of bank deposits, particularly towards their upper portions (Fig. 3).

iv. Levee surface sometimes shows salt-encrusted patches due to evaporation of saline water pools formed during overbank flooding.

v. Suspensional mud deposits on the topmost part of the river banks exhibit mud cracks or curly mud cracks (Fig. 4) and indicate subaerial exposure. Curly mud cracks are often associated with areas having algal matting.

vi. Rain prints are occasionally present on the topmost muddy surface.

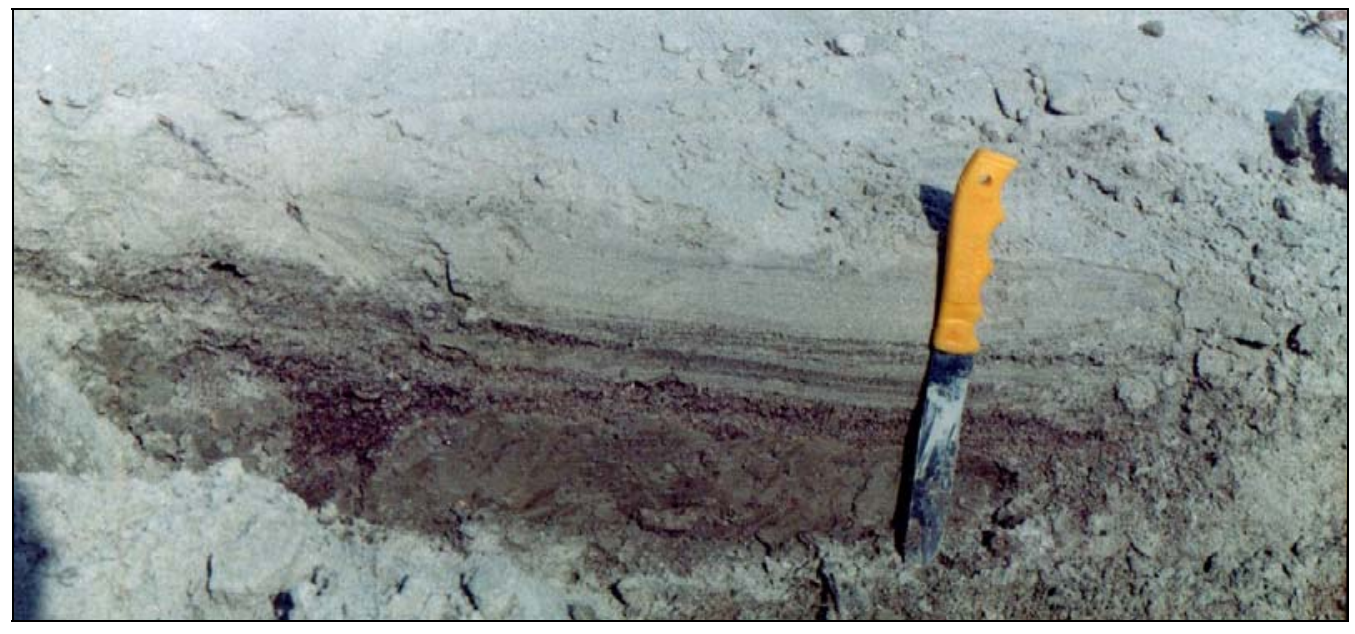

Fig. 2: Thinning of sand laminae and dominance of mud in the higher level. 
Open access e-Journal

Earth Science India, eISSN: $0974-8350$

Vol. 9 (III), July, 2016, pp. 130 - 149

http://www.earthscienceindia.info/

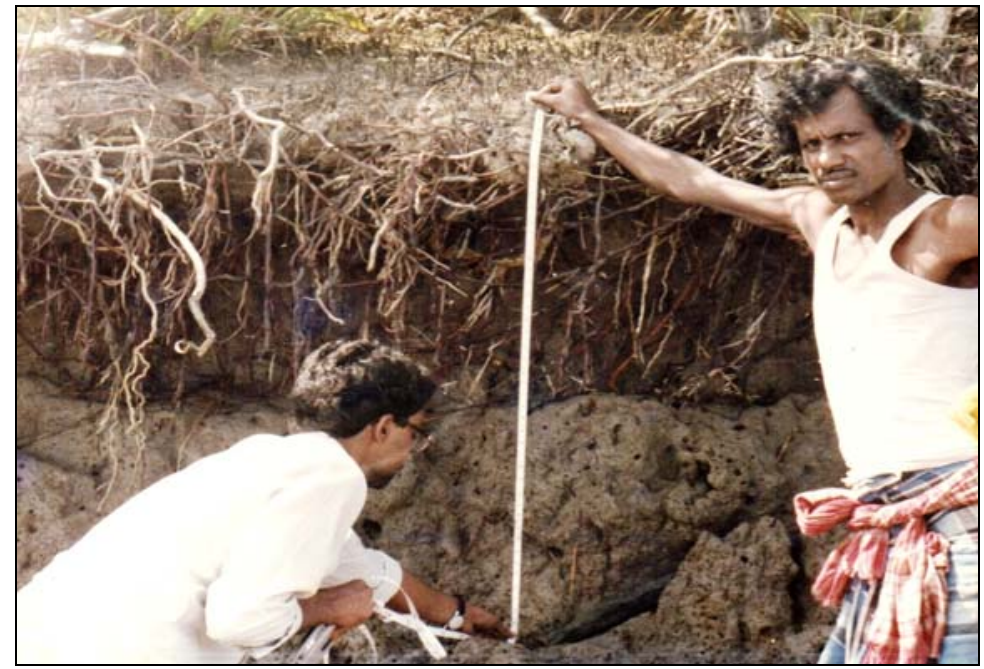

Fig. 3: Three distinct stratigraphic units with marked colour variations are seen. The intermediate stratigraphic unit is severely affected by plant roots and shows a sharp contact with the underlying unit. Note the erosional unconformity relation between these two units.

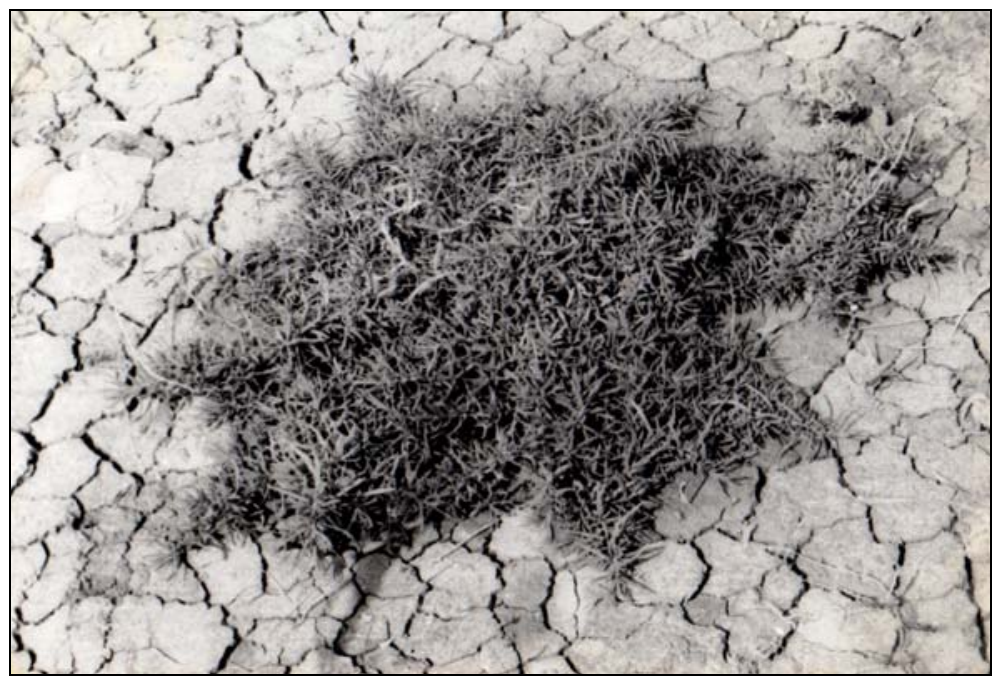

Fig. 4: Mud cracks in the supratidal river bank. Note the cluster of marsh vegetation, Suaeda nudiflora at the centre.

\section{Natural Levee/River Bank Morphology}

Both banks of Thakuran register evidences of local sagging (subsidence) in many instances. These areas of subsidence appear as troughs along the banks to be filled up partially or completely with newly accreting sediments. On the initial stage of compaction these sediments support mangrove saplings. In addition to subsidence, collapsing of banks is locally common due to over-steepening. Interbedding of sand with mud clast enriched layers is a common feature. Eventually, some portions of the upper levels of the banks slumped down to the lower levels. This leads to a mixing of different stratigraphic levels. The oversteepening of the banks is promoted by loosening of bank materials which interalia is caused by the following important factors: i) semi-diurnal tidal fluctuations and ii) hydrodynamic 
conditions that operate in meandering rivers in the form of helical flows. As a result the oversteepening of the banks slumped down to the lower levels.

In vertical sections the bank deposits are separable into three units based on colour from the top to the mean low water line. The bank top is dominated by mangrove species Phoenix paludosa, Ceriops decandra and Excoecaria agallocha (Fig. 5). Thakuran River bank shows abundant occurrence of Phoenix paludosa vegetation (Fig. 6). The top stratum mud deposits (up to $2 \mathrm{~m}$ thickness) are vigorously disturbed by the penetration of mangrove roots up to a depth of $1 \mathrm{~m}$ or so. The immediately underlying unit is $2 \mathrm{~m}$ thick, yellow mud. The unit (generally of $1.5-2 \mathrm{~m}$ thickness) is profusely bioturbated by crab burrows and penetration of mangrove rootlets. The muddy burrow walls and root affected mud cliffs display clear evidences of oxidation marked by brown colour of sediments. The lowermost unit of the banks (up to $2 \mathrm{~m}$ thickness) is less affected by bioturbational disturbance. In majority of the cases, the topmost unit has an erosional contact with the underlying intermediate unit, whereas no such erosional contact is recognizable between the intermediate and the lowermost units excepting a distinct colour variation.

In areas of old natural levees with more stable and compact substratum, the mangrove plants attain heights above $5 \mathrm{~m}$. Occasionally, these stable banks with an area of some tens of square meters collapse enblock together with the strong mangrove trees. The tree trunks often remain in an upright to slightly tilted position even after a vertical fall of $3 \mathrm{~m}$ or more (Fig. 7). Bank erosion of high magnitude is noticed in areas of severe wave actions near the mouth of Thakuran. The muddy river bank perches over the sandy platforms gently sloping riverward (Figs. $8 \& 9$ ). The top stratum unit is $0.65 \mathrm{~m}$ thick and supports dense mangrove forests on its surface. This greyish yellow unit is profusely traversed by roots of mangroves. The underlying unit is $0.9 \mathrm{~m}$ thick, yellow mud with intense bioturbation. Below this, a 0.35 $\mathrm{m}$ thick dark brown muddy unit is followed by the bottommost $1.1 \mathrm{~m}$ thick greyish mud with more intense bioturbation.

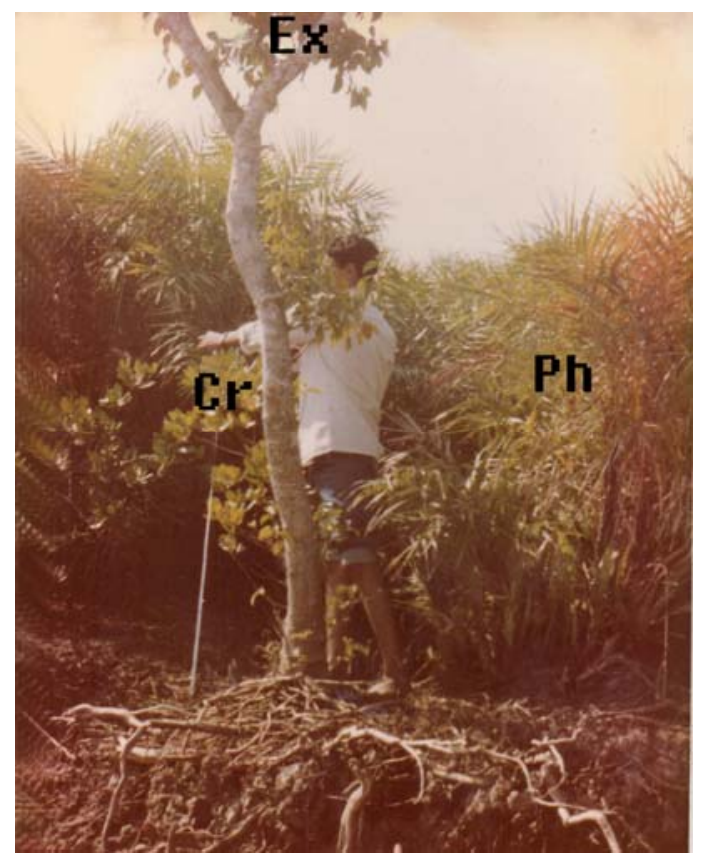

Fig. 5: Thakuran river bank at Dhanchi showing occurrence of various mangrove species. 'Ph' stands for Phoenix sp, 'Cr' stands for Ceriops sp and 'Ex' for Excoecaria sp. 


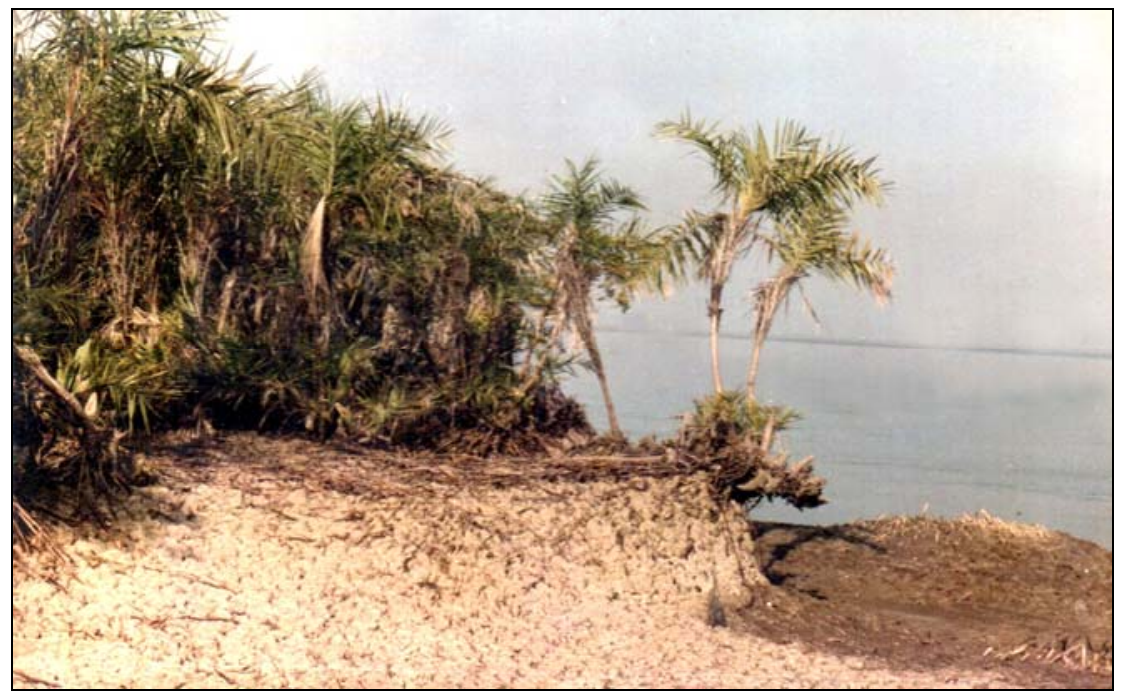

Fig. 6: Thakuran River bank showing occurrence of Phoenix paludosa vegetation.

At the confluence of the river and the Bay of Bengal (e.g. Bulchery Island) certain transverse mud bars $(30 \mathrm{~m}$ long and $10 \mathrm{~m}$ wide) get exhumed in low tides. These isolated bars, very commonly, reveal direct connections with the bank and raise their heads up to $2 \mathrm{~m}$ above low tide level. The bars exhibit a tendency of riverward tapering away from the bank. The space in between two consecutive mud bars ranges from $50 \mathrm{~m}$ to $150 \mathrm{~m}$. The exposed portions are often segmented by the passage of very narrow creeks, alignments of which are more or less parallel to the direction of tidal currents (Das and Bhattacharya, 1994).

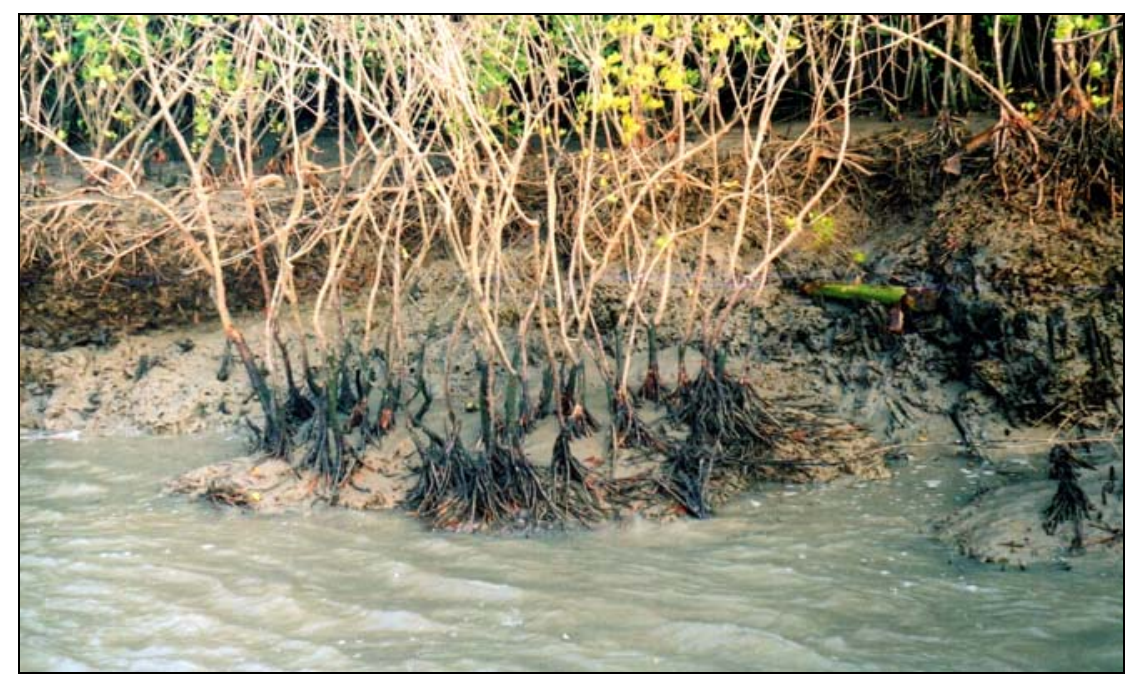

Fig. 7: Collapsing of the upper stratigraphic level of the bank containing Ceriops sp to the lower level leads to amalgamation of material and colour. Note the upright nature of the vegetation hummock even after a vertical fall of 3-4 meters. 


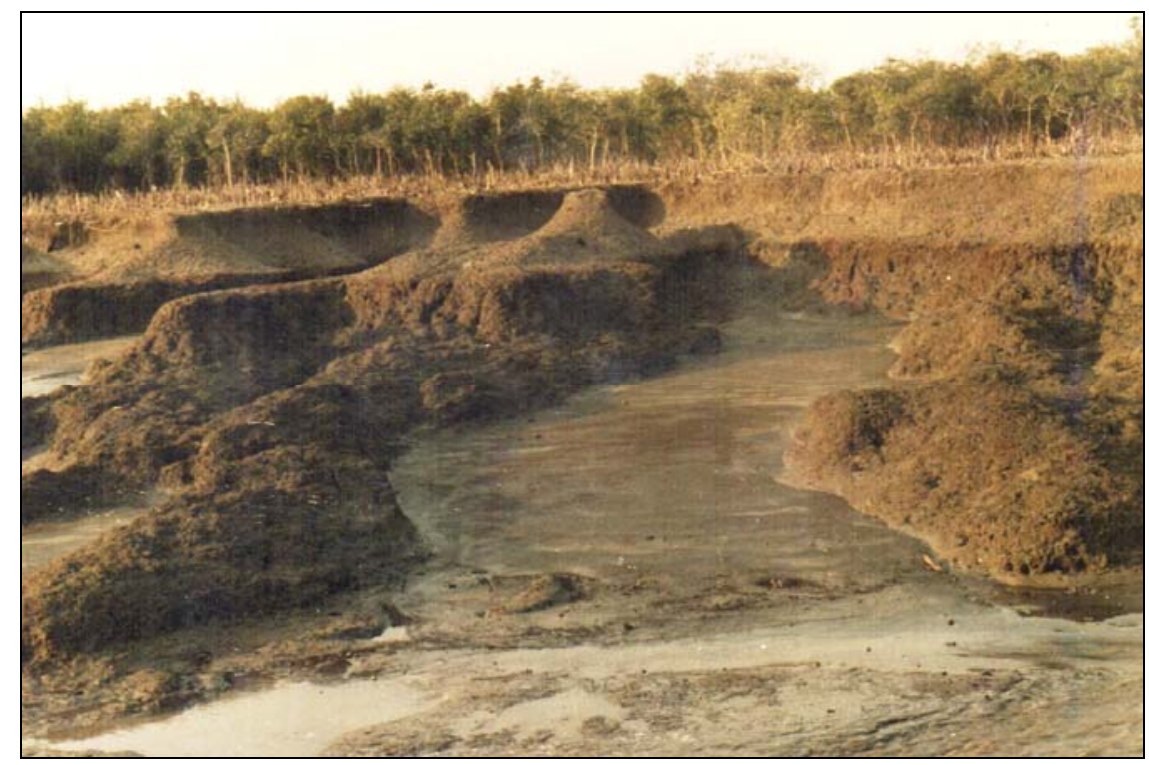

Fig. 8: Severe erosion near mouth of Thakuran at Dhanchi. The bank slopes down into gentle platforms. Note the conspicuous nature of erosional mud ridges.

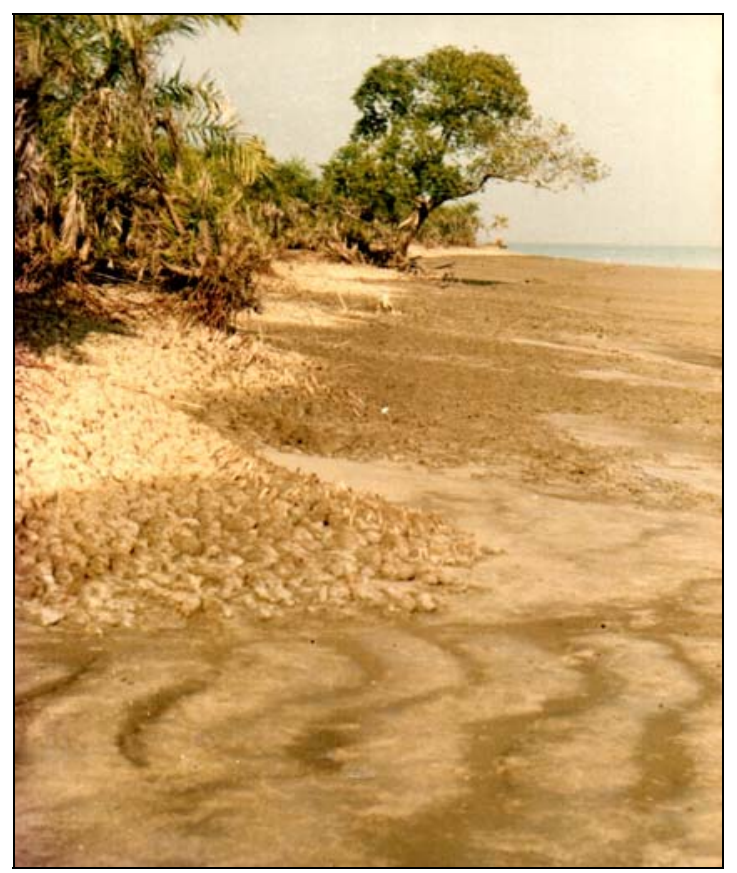

Fig. 9: Trains of backwash ripples on sandy swash platform. Supratidal mangrove mud slumps over sandy platform.

Somewhere, relict mud bars in the form of small isolated patches are present within the marginal waters. These relict bars are truly remnants of transverse mud bars and represent a particular state of their evolution. Removal of material is generally initiated by the tidal currents flowing through small creeks traversing the transverse mud bars. As a result, bank 
Open access e-Journal

Earth Science India, eISSN: $0974-8350$

Vol. 9 (III), July, 2016, pp. 130 - 149

http://www.earthscienceindia.info/

erosion takes place in the piecemeal manner which adds to the processes of lateral shifting of the river course. This observation, thus, leads to conclude that piecemeal mechanism of bank erosion enhances the process of tidal river or tidal creek migration in addition to the processes applicable for the shifting of meandering streams having unidirectional flow (Das, 2015).

The stretches of banks in between the transverse mud bars often exhibit collapsing and refilling by yellow sandy sediments forming a platform with a slope range from $3^{0}$ to $5^{0}$ towards the river. Repeated washing of the mud banks often gives rise to flow of muddy slur over the sandy platform. This explains the usual sharp contrast between the lower sandy and the upper muddy units.

\section{Colour Significance of Stratigraphic Units}

Colour of the sedimentary units can be divided into four kinds, viz., i) greenish yellow; ii) yellow; iii) yellowish brown to dark brown and iv) grey to dark grey. The yellow colour is because of staining by ferric compounds and indicates an oxidizing environment. The difference shades of yellow to brown are because of the variation in state of oxidation. The grey to dark grey colour implies a reducing environment and reflects a colour state traditional to those of yellow and green. The green colour is the outcome of adsorption of ferrous and chlorophyll related compounds mostly available from mangrove forests (Pantin, 1969; Swift and Boehmer, 1972; Owens, 1981; Stanley and Hait, 2000).

The colour variation has a definite stratigraphic relevance. The greenish yellow laminated units towards the upper part of the sequence indicate relatively greater oxidation because of exposure. The grey to dark grey muddy units at depth of 3 to $4 \mathrm{~m}$, on the contrary, reflects a more reducing environment. Local occurrences of isolated small patches of mixed yellow and greenish yellow colour within the grey to dark grey muddy units suggest foundering of upper units.

\section{Point Bar}

The river Thakuran is macrotidal from its mouth to $40 \mathrm{~km}$ upstream. Thereafter, it is mesotidal (2 to $4 \mathrm{~m}$ tidal range) up to its extreme upstream where it meets the Matla River. The river is generally sinuous to meandering and is characterised by a limited number of point bar deposits (Table-1) where deposition takes place laterally on the convex sides of the meander bends. The sandy point bar deposits in the macrotidal stretch more and more towards sea are gradually replaced landward by mesotidal gently inclined laterally accreting deposits identical to large-scale "epsilon cross stratification" or ECS (Fig. 10) of Allen (1963) "longitudinal cross-bedding" of Reineck and Singh (1980).

The point bars of Thakuran River are generally fulcate to crescentic in shape and extend for $0.1 \mathrm{~km}$ to $6 \mathrm{~km}$ in length and $0.2 \mathrm{~km}$ to $1.1 \mathrm{~km}$ in breadth (Table-1). Maximum height of point-bars from mean low water level is variable from $2-4 \mathrm{~m}$. The length-breadth ratio $(\mathrm{L} / \mathrm{B})$ of the point bars nicely conforms that of the meander bends. Sometimes, two to three point bars coalesce along their lengths to give rise to their extremely elongated shapes.

Alternate sand-mud stratifications up to $30 \mathrm{~cm}$ thickness are observed on the riverward margins of the point bars at low tide. Trench sections in the point bars also reveal same pattern of alternation of sand-mud laminae with gentle riverward dip. Barring localized occurrences of reversing ripples, longitudinal ripples (Fig. 11) and wave ripples, the point bar surface is mostly devoid of any other large-scale bedforms. Human interference very often badly disturbs and obliterates the small-scale bedforms on point bar surface. 
Table-1: Length, Breadth and Length-Breadth ratio of the point bars of Thakuran River.

\begin{tabular}{|l|c|c|c|}
\hline Locality & $\begin{array}{c}\text { Length (L) } \\
\text { (in km) }\end{array}$ & $\begin{array}{c}\text { Breadth (B) } \\
\text { (in km) }\end{array}$ & L/B \\
\hline Kishoripur & 1.25 & 0.25 & 5.0 \\
Madhusudanpur & 0.1 & 0.20 & 0.50 \\
Madhabpur & 0.5 & 0.63 & 0.79 \\
Sikirhat & 2 & 0.60 & 3.30 \\
Bhubankhali & 4.5 & 0.4 & 11.25 \\
Damkal & 3 & 0.75 & 4.0 \\
Maipit & 4 & 0.63 & 6.35 \\
Dakshin Kashinagar & 5 & 0.50 & 10.0 \\
Upendranagar & 0.6 & 0.85 & 0.70 \\
Sridharnagar & 6 & 0.63 & 9.52 \\
Dhanchi & 5.5 & 1.10 & 5.0 \\
Bulchery & 4 & 0.50 & 8.0 \\
\hline
\end{tabular}

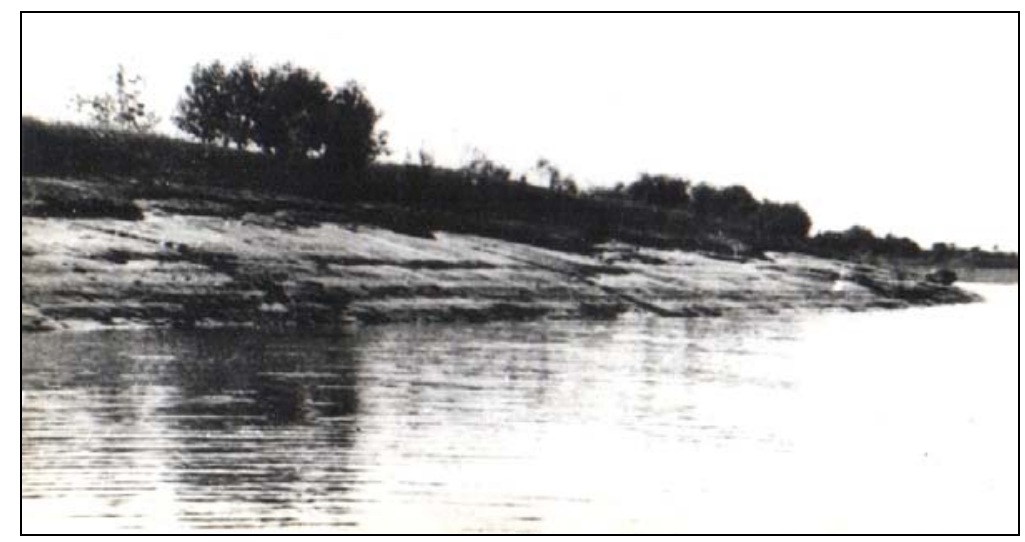

Fig. 10: Epsilon Cross Stratification (ECS) in the point bar of Thakuran. Background is with mangrove vegetation.

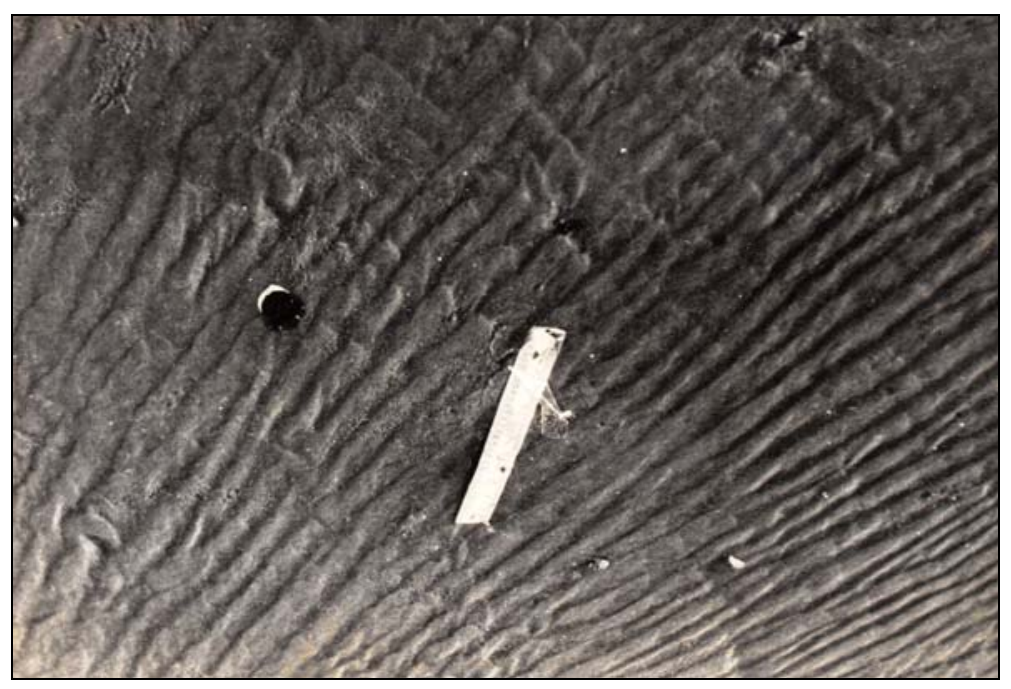

Fig. 11: Longitudinal ripples formed by waves and tidal currents. Ripple train is along the direction of current. 
Open access e-Journal

Earth Science India, eISSN: $0974-8350$

Vol. 9 (III), July, 2016, pp. 130 - 149

http://www.earthscienceindia.info/

\section{ECS within Point bar Deposits}

Large-scale epsilon cross-stratifications (ECS) are gently inclined towards the river direction. The stratifications run parallel to the upper surface of the point bars. Thickness of cross-stratified units ranges from 2 to $4 \mathrm{~cm}$. The inclination of the cross-beds averages $15^{\circ}$ and varies between $10^{\circ}$ and $20^{\circ}$. The ECS of Thakuran River are analogous in dimension to that of the Cretaceous McMurry Formation of Athabasca oil sands (Rahmani, 1988) and the Recent Willapa River point bar deposits of USA (Smith, 1988).

ECS differs in origin from the cross-stratifications produced by migration of ripples and megaripples (Reineck and Singh, 1980). Lateral shifting of point-bars facilitates epsilon cross-stratifications to run parallel to the current direction (Smith, 1988). Large-scale ECS are useful for interpreting depositional environments (Oomkens and Terwindt, 1960; Van Straaten, 1961; Bridges and Leeder, 1976; and Mossop and Flach, 1983).

A muddy substratum supporting mangrove plants overlies the ECS units in many places and this yields a fining upward sequence for the point bar deposits. Laminations in the muddy units are obscured because of profuse bioturbation and penetration of mangrove roots. Mangroves contribute a substantial quality of organic matter in the uppermost unit. Occasionally mud clasts are trapped within lower stratigraphic units being ripped out from the upper stratigraphic horizons. A clear unidirectional current can be inferred from the ECS. Their strike direction is essentially parallel to the river banks.

\section{Mid Channel Bar}

Mid channel bars are the river bed geomorphic bodies which are quite conspicuous in the central part of the Thakuran River of Sunderbans. These constitute a series of depositional sites on the river bed itself and are relatively more common from $10 \mathrm{~km}$ upstream of the mouth of the river. They occur as isolated elongated elliptical depositional shoals extended along the river channel axis. The actual extension of the bars and their limits were studied during ebb tides only (Fig. 12). The mid channel bars generally maintain a gradual upward convexity having lengths ranging from 2.1 to $4.75 \mathrm{~km}$ and breadth 1.0 to $3.7 \mathrm{~km}$ (Table-2). The height ranges from 2 to $4 \mathrm{~m}$ above mean low water level. They migrate upstream with the movement of flood tidal currents along the main flood channel. At Paschim Sripatinagar, $39 \mathrm{~km}$ upstream from the confluence of the river and Bay of Bengal the rate of upstream migration of a bar has been calculated to be $1.5 \mathrm{~km}$ in 90 years, with a rate of $16 \mathrm{~m}$ per year (Das, 2015). Bedforms and grain size characteristics of this mid channel bar have been studied during ebb when the bar surface was exhumed with all its bedform characteristics.

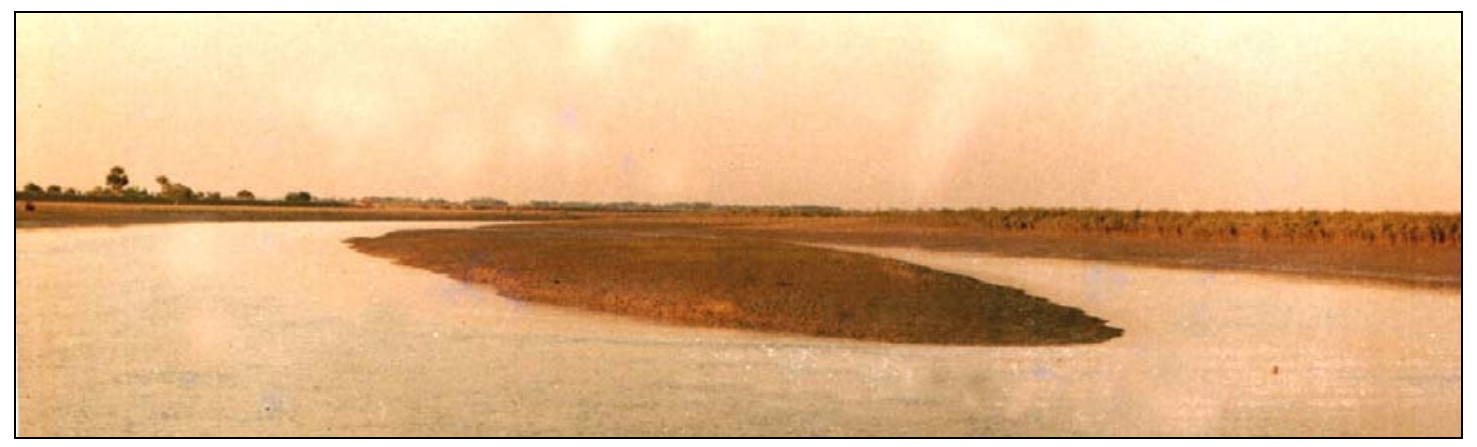

Fig. 12: A recently raised mid channel bar near Bhubaneswari Dwip as seen in ebb tide. The bar is with elliptical outline and gentle upward convexity. 
Many of these mid channel bars are traversed by meandering creeks and are seen to be active during the low tides. The mid channel bars that occur farthest from the sea face are generally muddy, whereas, those nearer the sea are mostly sandy. Some mid channel bars that occur in the middle stretches of the rivers exhibit excellent grain size differentiation from their northern (landward) to the southern (seaward) extremities. Generally the southern halves of these bars are sandy and the northern halves are muddy in nature. The sandy halves often show a distinct separation of the flood and ebb currents as bedforms representative of these two currents are more clearly developed in the cohesionless sand grains. Sand flats with small and large scale bedforms dominate over the downstream portion of the shoals, whereas, mudflats with less physical structures and abundant biogenic activity of Macoma bermanica, Anadera granosa and Placenta sp characterize the upstream portion of the shoals. The organic activity further modifies the physical process and enhances sediment accumulation.

Table-2: Length, Breadth and Length-Breadth Ratio (L/B) of the mid channel bars of the Thakuran River.

\begin{tabular}{|l|c|c|c|}
\hline Locality & $\begin{array}{c}\text { Length (L) } \\
\text { (in km) }\end{array}$ & $\begin{array}{c}\text { Breadth (B) } \\
\text { (in km) }\end{array}$ & L/B \\
\hline Bhubaneswari Dwip & 3.15 & 1.05 & 3.0 \\
Damkal Dwip & 2.1 & 1.0 & 2.1 \\
Paschim Sripatinagar & 3.5 & 3.7 & 0.95 \\
Upendranagar & 2.5 & 1.1 & 2.27 \\
Rakhalpur & 2.45 & 0.9 & 2.72 \\
Sridharnagar & 3.7 & 2.8 & 1.32 \\
Dhanchi I & 3.0 & 1.25 & 2.4 \\
Dhanch II & 4.75 & 1.1 & 4.32 \\
\hline
\end{tabular}

In the northern half of Paschim Sripatinagar bar, sporadic occurances of small-scale longitudinal ripples and wave ripples are observed. Megaripples are absent. The surface sediments are dominantly muddy with clayey silt. Graphic mean size $\left(\mathrm{M}_{\mathrm{Z}}\right)$ of surface sediments ranges from 4.86 phi to 6.45 phi and sorting from 0.47 to 1.45 phi, i.e. well sorted to moderately sorted (Das, 2016a). The longitudinal ripples here run parallel to the current and are localized in cohesive muddy areas. They are truly erosive forms in which current erodes in the ripple troughs and simultaneously maintains the ripple crests (Reineck and Singh, 1980). Propagation of translatory waves at right angles to the currents in these shallow water muddy areas gives rise to wave ripples with crests at right angles to the longitudinal ripples.

The bar surface is more or less flat, but owing to intense bioturbation it is full of mounds and pits. All these attributes suggest that in the northern half of the mid channel bar bedload transport is limited and in this respect the sediment transport characteristics resemble those on tidal flat. This portion of the mudflat is characterized by the settling of some mangrove saplings (mainly Avicennia marina) and the sea grass (Porterasia coarctata). Both the forms intermingle with each other in some places (Fig. 13). Patches of marshy areas with Porterasia sp on the sandy mud substratum dovetail with mudflats.

The southern portion of the sandy mid channel bar is sculptured with ripples, megaripples and sand waves of various morphological types and scales. The area, thus, displays relief features of different orders on the bar surface. The surface sediments have mean grain size $\left(\mathrm{M}_{\mathrm{Z}}\right)$ from 2.02 to 3.55 phi (medium to fine sand), sorting $\left(\sigma_{1}\right)$ from 0.22 to 0.84 phi (very well sorted to moderately well sorted). Influence of flood flow is reflected in the trains of sand waves and megaripples. The ebb flow, however, besides changing the 
Open access e-Journal

Earth Science India, eISSN: $0974-8350$

Vol. 9 (III), July, 2016, pp. 130 - 149

http://www.earthscienceindia.info/

morphology of the flood-oriented bedforms, is also responsible for generation of small-scale ripples. The flood and ebb flow directions over this mid channel bar have been interpreted from the orientation of various bedforms (Das, 2016b).

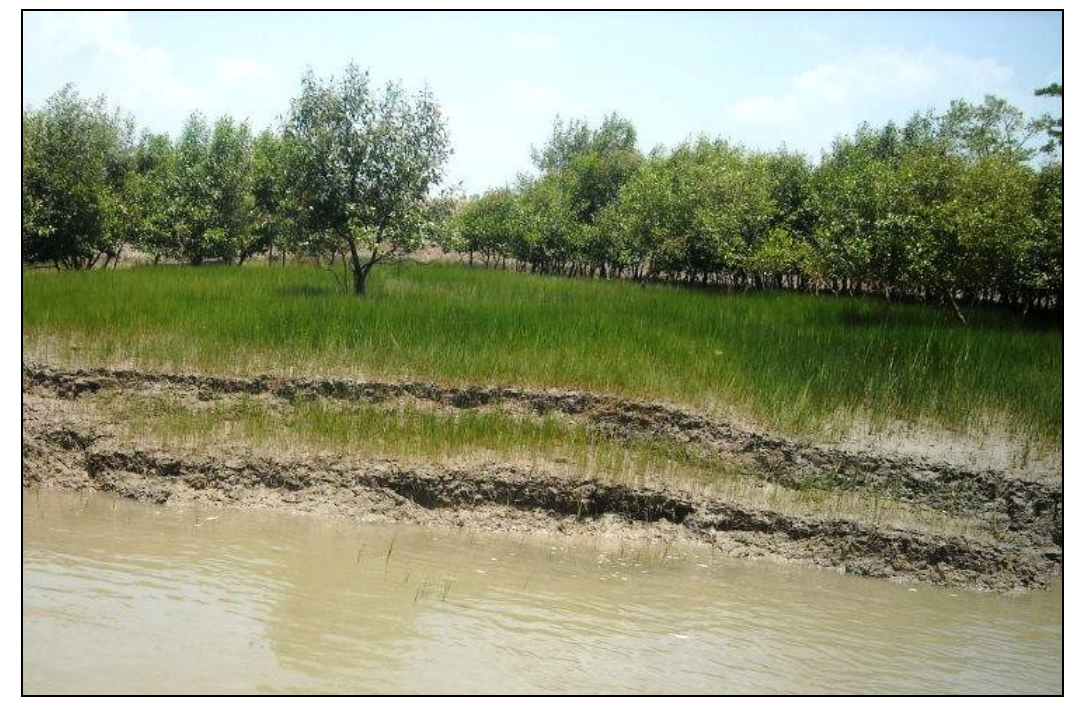

Fig. 13: Intermingling of saplings of Avicennia sp (mangrove) and Porteresia sp (sea grass) on the mud flat of mid channel bar.

A drastic change in the mode of transport of material is well documented from the Paschim Sripatinagar mid channel bar. The northern half of the bar is dominated by suspended load sediments whereas, the southern portion marks the prime influence of bed load deposits. Because of quick shifting of sand in this portion of the mid channel bar, the intensity of bioturbation is less although some crawling, resting and browsing traces of crabs, gastropods and bivalves are present.

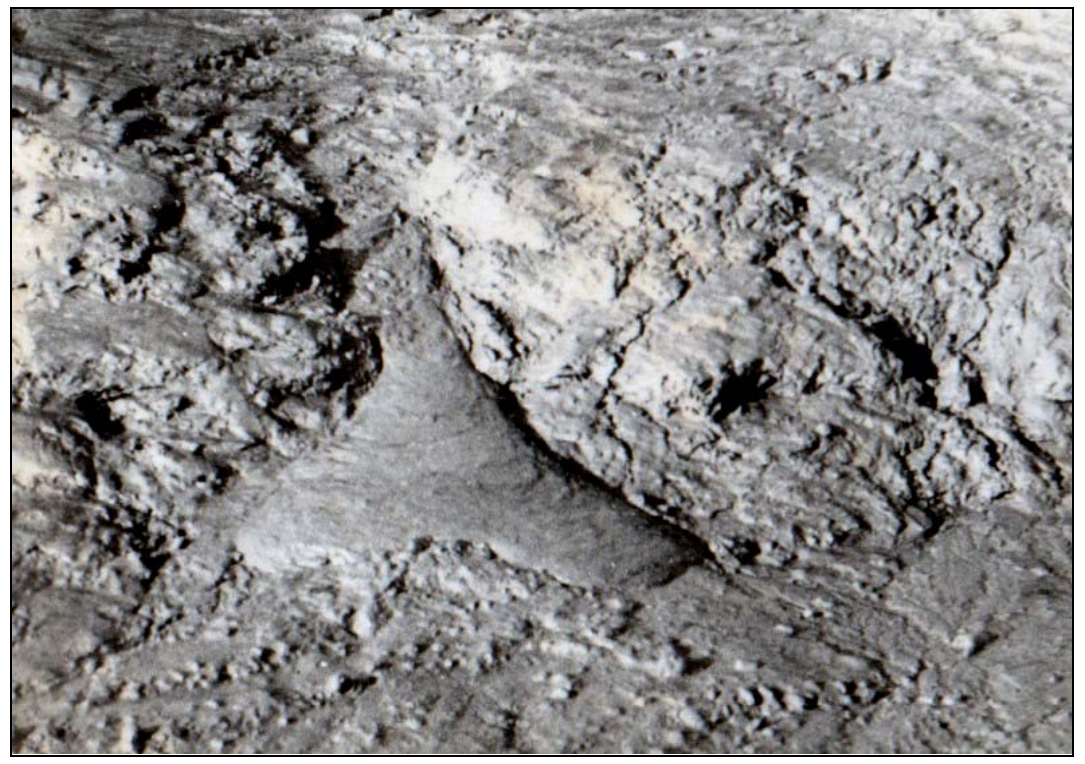

Fig. 14: A muddy microdelta on the slope of a creek. Note the transverse growth marks on the surface and lobed nature of the lee-side. 
A large number of meandering creeks traverses this mid channel bar exposing its lamination patterns. The creeks are of variable length $(20 \mathrm{~m}$ to $500 \mathrm{~m})$ and width (up to 15 $\mathrm{m})$. Lee-slope orientations of current ripples generated along these creeks are often different from those occurring outside the creek boundaries. Slumping and collapsing of creek margin and concurrent deposition of the eroded material at the mouth of the creeks develop both sandy and muddy micro-deltas (Fig. 14).

Textural studies of samples collected up to a depth of $120 \mathrm{~cm}$ with the help of auger revealed a general coarsening upward of mean grain size $\left(\mathrm{M}_{\mathrm{Z}}\right)$ i.e. a ' $\mathrm{Cu}$ ' sequence (Fig. 15). This upward coarsening of mean grain size is, however, noticed in the mid channel bar sediments occurring up to $40 \mathrm{~km}$ stretch upstream (marked by Paschim Sripatinagar mid channel bar) from the mouth of the Thakuran River. This is perhaps due to landward advancement of the river mouth sand by strong waves and flood currents.

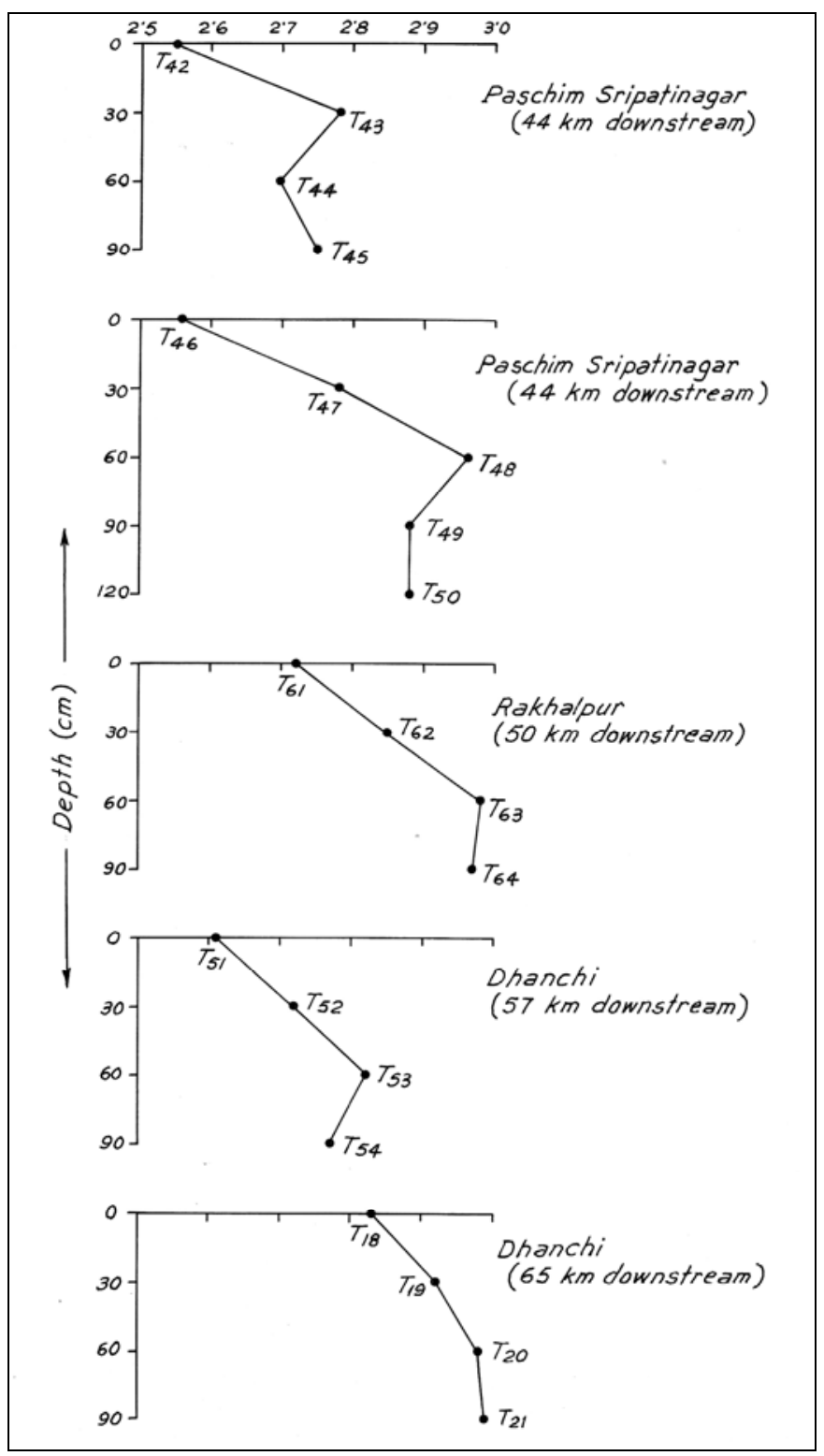

Fig. 15: Coarsening upward (CU) sequence in mid channel bar samples of Thakuran River. 


\section{Swash Platform}

Crescentic bar seen near the mouth of the Thakuran River at Dhanchi experiences wave rush up and backwash in its intertidal zone. This zone behaves like swash platforms (Oertel, 1972) where the accretionary sandy bar sediments are reworked by wave action and exhibit features like that of sandy beaches. Instead of seaward dip, inclination of the swash bar surface is towards the funnelled estuary. The elongation axis of the swash platforms is almost at right angles to the shoreline (Fig. 16).

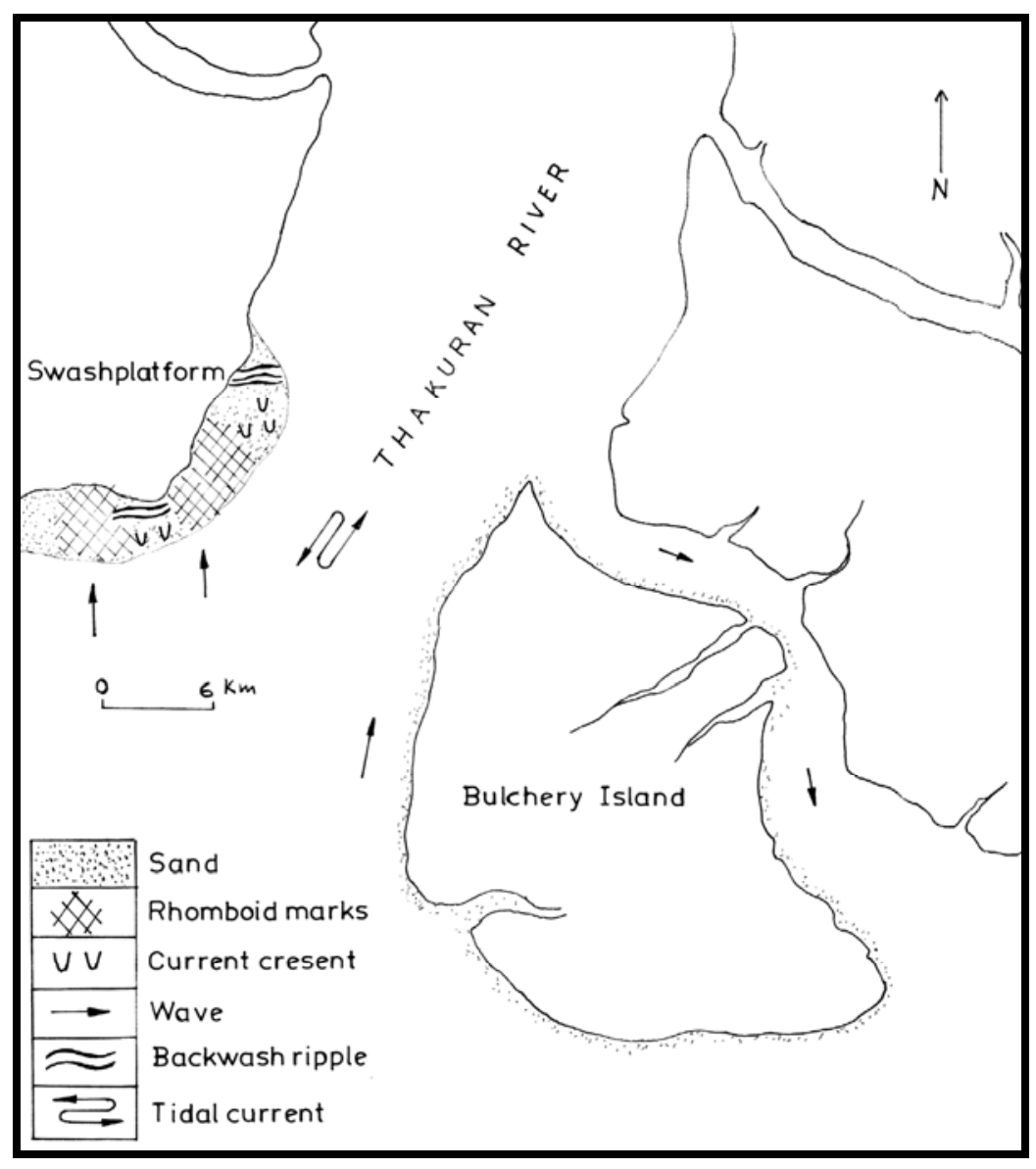

Fig. 16: Map showing location of swash platform. Grain size and surface sedimentary structures are also shown.

Morphologically, the swash platforms show gently dipping surfaces $\left(4-5^{0}\right)$ with minor undulation on higher topographic areas. These undulations are due to the presence of the backwash ripples or low amplitude antidunes which characterise the upper foreshore zone of most beaches. The maximum advance of wave swash is marked by swash marks made up of wood pieces, weeds and mangrove leaves (Figs. $17 \& 18$ ). The mid intertidal zone of the platforms shows major undulations due to the presence of megaripple trains. Some convex upward ridges on the platforms are ornamented both by large-scale and small-scale rhombhoid marks. The lower most stretch of the platforms is characterised by abundant current crescents, rill marks and small scale wave ripples. At the distal end of the platforms 
where they merge into the muddy mangrove banks, the sandy swash platform are underlain by cohesive mud that supports luxuriant mangrove vegetation, particularly Phoenix paludosa forests, the suitable abode for the famous Royal Bengal Tiger of Sunderbans. The overlying mud encroaches the sandy platform showing sinuous train. Sometimes, portions of upper muddy bank sink down to the low-lying sandy substratum resulting in entrapment of mud chunks within sandy units. Thus the surface roughness of the swash platform is the manifestation of bedform patterns and their spacing characteristics.

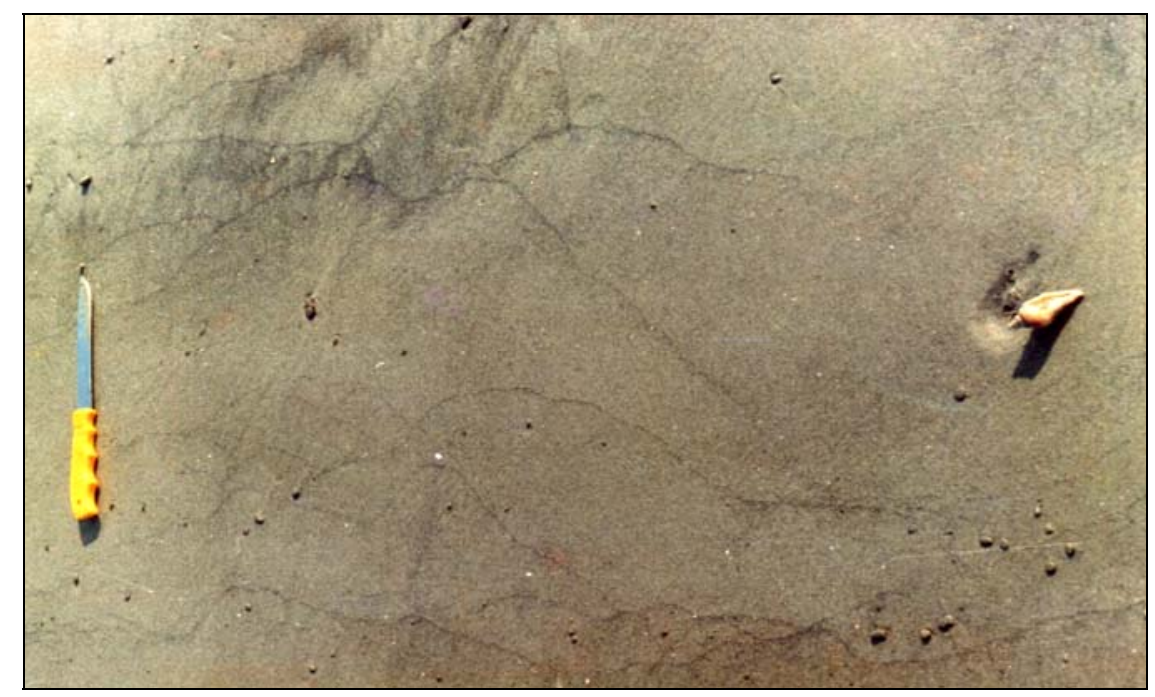

Fig. 17: Swash marks on sandy swash platform. Convexity of the marks is in the riverward direction. A current crescent is seen to the right of the photograph. Opening of the arms of the current crescent also indicates the same riverward direction. The gastropod shell has been drifted up by waves after the formation of current crescent. Knife is $26 \mathrm{~cm}$.

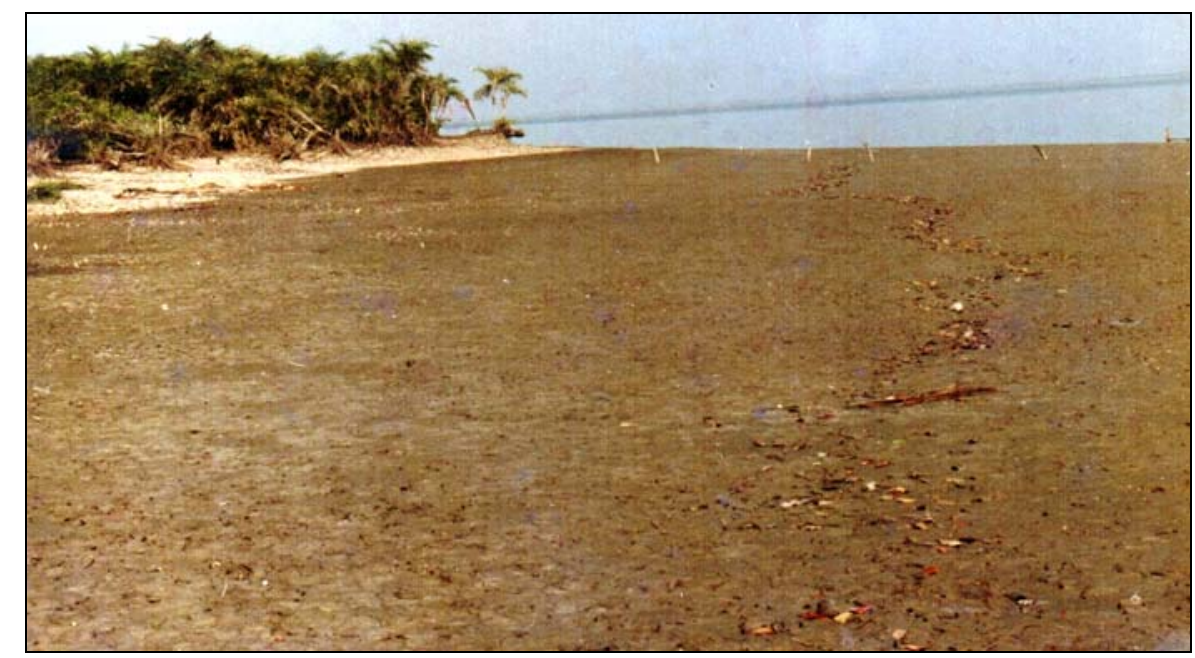

Fig. 18: Swash marks on sandy swash platform. The marks have become pronounced because of concentration of mangrove leaves at the maximum advance of wave swash. Supratidal bank supporting mangrove is seen on the background. 


\section{Wash over Flat}

The wash over flat occupies a very small part of the geomorphological spectrum of the Thakuran River basin. South-west of the Dhanchi Island at the mouth of river a wide sandy wash over flat of channel-fill origin has been identified. The flat has a gradual seaward slope ranging from $3^{0}-6^{0}$.

The wash over flat is generally intertidal with ripples and rills as the dominating surface features. The rills produced mainly by the backwash flow, make a complex network of branching up to the sea face. The upper supratidal portion is characterised by a series of aeolian dunes, many of which are conspicuous by the accumulation of mangrove leaves. Exotic boulders and variable sizes of oyster shells are strewn all over the flat and give definite evidences of the repeated reworking of the surficial sediments. Stability of the flats is greatly reduced by the felling of mangrove trees, the upright trunks of which stand bare on the sandy wash over flat surface.

\section{Ebb-Tidal Delta}

The Bulchery Island exhibits the most prominent sites of sedimentation at the confluence of the Thakuran River and the open sea. This huge island (approximately $7 \mathrm{~km}$ across) is an ebb-tidal delta. The narrow Gokultali creek (locally known as Gokultali gang) is the ebb channel whereas, the course of Thakuran River acts as the flood channel. The upper surface of this island remains exposed even at high tides throughout the year. The island is truly an ebb-tidal delta (Hayes, 1976). The northern part of the mouth bar is protected from wave action and is under the influence of tidal currents. The southern parts, on the other hand, faces the Bay of Bengal and experiences severe wave attack. The spring tidal amplitude is as high as $6 \mathrm{~m}$ or more (macrotidal). This ebb tidal delta or the river mouth bar originates where the ebb-flow is countered by the incoming refracted waves from the Bay of Bengal (Hubbard, Oertal and Nummedal, 1979). According to Hayes (1976), the ebb-tidal deltas are more characteristics of a mesotidal setting. Elliott and Gardiner (1981), however, reported their occurrence in a macrotidal framework.

The intertidal and supratidal deposits of the Bulchery Island are clearly discernable. The intertidal zone exhibits dovetailing of sand and mud for an expanse of $800 \mathrm{~m}$. The supratidal zone has an expanse of 170 to $180 \mathrm{~m}$ and is composed of non-cohesive sands of reddish yellow colour inferring a greater rate of oxidation. Bioturbational effects are quite common. A gradual change from intertidal to supratidal environment is readily recognizable from the marginal to the topmost part of the island. The supratidal sands are very fine and well-sorted. The island is dissected by a number of tidal creeks of sinuous nature. These creeks are generally ephemeral and are subjected to change their courses with time. Natural creek sections often reveal alternations of sand and mud layers of variable thickness ranging between 10 and $45 \mathrm{~cm}$.

\section{Sand-Body Geometry of Geomorphic Zone}

Four different types of sand bodies characterizes of four geomorphic set ups have been recognized in the Thakuran basin (Table-3). Dimensions of sand bodies, grain size, bedforms, and internal sedimentary structures stand as the principal parameters to characterize each of them (Coleman et al., 1988, Harris, 1988; Terwindt, 1988 and Banerjee, 1989). Despite some overlapping these parameters present clear distinctiveness of different types of sand bodies recognized. 
Table-3: Diagenostic features of four basic types of sand bodies of different geomorphic zones

\begin{tabular}{|c|c|c|c|c|}
\hline $\begin{array}{c}\text { Parameters } \\
\text { of sand body } \\
\text { geometry }\end{array}$ & $\begin{array}{l}\text { Mid-channel } \\
\text { bar }\end{array}$ & $\begin{array}{c}\text { River bank } \\
\text { (Natural } \\
\text { Levees) } \\
\end{array}$ & $\begin{array}{c}\text { Point bar / } \\
\text { Swash } \\
\text { Platform }\end{array}$ & $\begin{array}{l}\text { Ebb Tidal } \\
\text { Delta }\end{array}$ \\
\hline Dimension & $\begin{array}{l}4 \mathrm{~km} \times 3.54 \mathrm{~km} \\
\text { x } 14 \mathrm{~m}\end{array}$ & $\begin{array}{l}6 \mathrm{~km} \times 1.5 \\
\mathrm{~km} \times 18 \mathrm{~m}\end{array}$ & $\begin{array}{l}5 \mathrm{~km} \text { x } 0.5 \mathrm{~km} \\
\text { x } 17 \mathrm{~m}\end{array}$ & $\begin{array}{l}9 \mathrm{~km} \times 6 \mathrm{~km} \times \\
16 \mathrm{~m}\end{array}$ \\
\hline Grain size & 2.02 to $2.96 \mathrm{Phi}$ & $\begin{array}{l}2.62 \text { to } 2.92 \\
\text { Phi }\end{array}$ & $\begin{array}{l}2.58 \text { to } 2.61 \\
\text { Phi }\end{array}$ & $\begin{array}{l}2.53 \text { to } 2.77 \\
\text { Phi }\end{array}$ \\
\hline Bedforms & $\begin{array}{l}\text { Sandwaves, } \\
\text { Megaripples } \\
\text { Ripples, } \\
\text { (Linguoid, } \\
\text { Ladder-back, Flat- } \\
\text { topped), Rill } \\
\text { marks. }\end{array}$ & Small-scale & $\begin{array}{l}\text { Megaripples, } \\
\text { Reversing } \\
\text { ripples, } \\
\text { Backwash } \\
\text { ripples, Swash } \\
\text { marks, Current } \\
\text { crescents, Rill } \\
\text { marks }\end{array}$ & $\begin{array}{l}\text { Sandwaves, } \\
\text { Megaripples, } \\
\text { Ripples }\end{array}$ \\
\hline $\begin{array}{l}\text { Internal } \\
\text { structure }\end{array}$ & $\begin{array}{l}\text { Large-scale cross- } \\
\text { bedding. } \\
\text { Alternation of } \\
\text { sand and mud } \\
\text { couplets, Parallel } \\
\text { stratification }\end{array}$ & $\begin{array}{l}\text { Ripple-drift } \\
\text { lamination, } \\
\text { Parallel } \\
\text { lamination }\end{array}$ & $\begin{array}{l}\text { Epsilon cross- } \\
\text { bedding, } \\
\text { Alternate sand } \\
\text { and mud } \\
\text { lamination }\end{array}$ & $\begin{array}{l}\text { Large and } \\
\text { small-scale } \\
\text { cross bedding }\end{array}$ \\
\hline $\begin{array}{l}\text { Facies } \\
\text { Sequence }\end{array}$ & $\begin{array}{l}\text { Coarsening } \\
\text { upward }\end{array}$ & Fining upward & Fining upward & $\begin{array}{l}\text { Coarsening } \\
\text { upward }\end{array}$ \\
\hline
\end{tabular}

\section{Summary}

Geomorphological complexity of the Thakuran Basin of Sunderbans is important due to its depositional behaviour, sediment nature and characteristic structures, mudflats, tidal marshes, various bioturbation structures and luxuriant mangrove vegetation. The morphodynamics of the Thakuran tidal river, particularly its braided nature and enclosed landforms, play a vital role in shaping the geography of the drainage basin. The intricate network of meandering channel system has given rise to the formation of a number of islands through various processes of island formation in this tidal river. Different divisions of geomorphic environments have been identified along with their characteristic depositional and erosional features.

The hostile estuarine zone of the Thakuran River channel of the Sunderbans is highly vulnerable because of the interactions of many direct and indirect agencies. The geomorphic environments and facies of this river basin are diverse and interfinger in both lateral and vertical senses. The subaerial activities are often mixed with subaqueous processes. The shallow subaqueous deposits are again transported to deeper sea by submarine canyons. Recycling of shallow coastal deposits often disturbs the sediment distribution patterns and imports temporal and spatial variations of sediment budget.

The coastal zone at the confluence of the Thakuran River with the Bay of Bengal reveals various apparent accretional erosional sectors without showing a significant progradation of the shoreline for some time. This is because the bulk of sediment load carried from upland is transported to contribute to the Bengal deep sea fan - a mechanism similar to that described in the Bruun Rule which states that a generally sandy coastline with 
equilibrium profile will retreat (or remains steady!) in response to a rise of sea level relative to the land until the profile has been restored by sea floor accretion.

\section{References}

Allen, J.R.L. (1963) The classification of cross-stratified units with notes on their origin. Sedimentology, v. 2 , pp. 93-114.

Banerjee, I. (1989) Tidal structures in the Glauconitic Sandstone, Countess Field, Southern Alberta, Canada. pp. 89-97. In: G.E. Reinson (ed.) Modern and Ancient Examples of Clastic Tidal Deposits- A core and peel workshop. Canadian Society of Petroleum Geologists, Second International Research Symposium on Clastic Tidal Deposits, August 22-25, Calgary, Alberta, 126p.

Bhattacharya, A. (1999) Embankments and their ecological impacts: a case study from the Tropical low-lying coastal plains of the deltaic Sunderbans, India. pp. 171-180. In: Manfred Vollmer, Henning Grann (eds.) Large-scale constructions in coastal environments, Springer, 194p.

Bridges, P.H. and Leeder, M.R. (1976) Sedimentary model for intertidal mudflats channel with examples from the Solway Firth, Scotland. Sedimentology, v. 23, pp. 533-552.

Coleman, S.M., Berquist, C.R. Jr. and Hobbs, C.H. III (1988) Structure, age and origin of the bay mouth shoal deposits. Chesapeake Bay, Virginia. Marine Geology, v. 83, pp.95-113.

Coleman, J.M. (1969) Brahmaputra River: Channel process on sedimentation. Sedimentary Petrology, v. 3(2/3) spl issue, pp.129-139.

Das, G.K. (2015) Estuarine morphodynamics of the Sunderbans. Coastal Research Library. v.11. Springer, Switzerland, $211 \mathrm{p}$.

Das, G.K. (2016a) Sediment Grain Size. pp. 555 - 558. In: Michael J Kennish (ed.) Encyclopedia of Estuaries. Springer, 760p.

Das, G.K. (2016b) Sedimentary Structures. pp. 568 - 572. In: Michael J Kennish (ed.) Encyclopedia of Estuaries, Springer. 760p.

Das, G.K. and Bhattacharya, A. (1994) A piecemeal mechanism of bank erosion following subsidence: A case study from Thakuran River of deltaic Sunderbans, West Bengal. Journal Indian Society of Coastal Agricultural Research, v. 12, pp. 231-234.

Elliot, T. and Gardiner, A.R. (1981) Ripple, megaripple and sandwave bedforms in the macrotidal Loughor Estuary, South Wales, UK. Spl. Pub. Int. Asso. Sed., v. 5, pp. 51-64.

Harris, P.R. (1988) Large-scale bedforms as indicators of mutually evasive sand transport and sequential infilling of wide-mouthed estuaries. Sedimentary Geology, v. 57, pp. 273-298.

Hayes, M.O. (1976) Morphology of sand accumulation in estuaries: an introduction to the symposium. In: L.E. Cromn (ed.) Geology and Engineering. pp. 3-22, Estuarine Research. v. 2. Academic Press. New York.

Hubbard, D.K., Oertal, G. and Nummedal, D. (1979) The role of waves and tidal currents in the development of tidal inlet sedimentary structures and sand body geometry: examples from North Carolina, South Carolina and Georgia. J. Sed. Petrol., v. 49, pp.1073-1092.

Mossop, G.D. and Flach, P.D. (1983) Deep channel sedimentation in Lower Cretaceous McMurry Formation, Athabasca Oil Sands, Alberta. Sedimentology, v. 30, pp.393-409.

Oertel, G.E. (1972) Sediment transport on estuary entrance shoals and the formation of swash platform. J. Sed. Petrol., v. 42(4), pp. 528-563.

Oomkens, E. and Terwindt, H.H.J. (1960) Inshore estuarine sediments in the Harinvliet (Netherlands). Geol. Mijubouw, v. 39, pp. 701-710.

Owens, R. (1981) Holocene sedimentation in the north-western North Sea. pp. 303-322. In: S.D. Nio, R.J.E. Shiittenhelm and Tj. C.E. Van Weering (eds.) Holocene marine sedimentation in the North Sea basin. Spl. Pub. Int. Asso. Sediment, 515p.

Pantin, H.M. (1969) The appearance and origin of colours in muddy marine sediments around New Zealand. N. Z. J. Geology and Geophysics, v. 12, pp. 51-66.

Rahmani, R.A. (1988) Estuarine tidal channel and nearshore sedimentation of a Late Cretaceous epicontinental sea, Drumheller, Alberta, Canada. pp. 433-471. In: P.L. de Boer, A. Van Gelder and S.D. Nio (eds.) Tide-influenced Sedimentary Environments and Facies. D Reidal Publishing Company, 530p.

Reineck, H.E. and Singh, I.B. (1980) Depositional sedimentary environments. Springer Verlag, New York, 408 p.

Sarkar, S.K. and Basumallick, S. (1968) Morphology, structure and evolution of a channel island in the Barakar River, Barakar, West Bengal. J. Sed. Petrol. v. 38, pp. 747-754.

Smith, D.G. (1988) Modern point bar deposits analogous to the Athabasca Oil Sands, Alberta, Canada. pp $417-$ 432. In: P.L. de Boer, A. Van Gelder and S.D. Nio (eds.) Tide-influenced Sedimentary Environments and Facies, D Reidal Publishing Company, 530p. 
Stanley, D.J. and Hait, A.K. (2000) Holocene depositional patterns, neotectonics and Sunderbans mangroves in the Western Ganges- Brahmaputra delta. J. Coastal Research, v.16(1), pp. 26-39..

Swift, D.J.P. and Boehmer, W.R. (1972) Brown and grey sands on the Virginia Shelf: colour as a function of grain size. Bull Geol. Soc. Am., pp. 877-884.

Terwindt, J.H.J. (1988) Paleo-tidal reconstruction of inshore tidal depositional environments. pp 233-264. In: P.L. de Boer, A. Van Gelder and S.D. Nio (eds.) Tide-influenced Sedimentary Environments and Facies, D Reidal Publishing Company, 530p.

Van Straaten, L.M.J.U. (1961) Sedimentation in tidal flats areas. J. Alberta Soc. Petrol. Geol., v. 9, pp. 203-213.

(Submitted: 17.05.2016; Accepted: 22.06.2016) 